http:/www.journals.zu.edu.eg/journalDisplay.aspx?Journalld=1\&queryType=Master

\title{
EFFICACY OF SOME INERT DUSTS AGAINST THE RICE WEEVIL, Sitophilus oryzae (L.) ON WHEAT AND RICE GRAINS
}

\author{
Manar Y. Amin ${ }^{1 *}$, M.M.I. Aamir ${ }^{2}$, R.A. Mohamed ${ }^{1}$ and S.M. Abd-Alla ${ }^{2}$ \\ 1. Plant Prot. Res. Inst., Agric. Res. Cent., Dokki, Giza, Egypt \\ 2. Plant Prot. Dept., Fac. Agric., Zagazig Univ., Egypt
}

Received: 04/10/2016 ; Accepted: 28/11/2016

\begin{abstract}
The present work aimed to study the efficacy of some inert dusts, i.e., calcium carbonate $\left(\mathrm{CacO}_{3}\right)$, white cement, black cement, sand, espidage, phosphate rock, sulfur flowers, talc powder (Mgo), animal dung ash, zinc dust, diatomaceous earth (DE), silica gel and katel-sous (Ks) against adults of the rice weevil, Sitophilus oryzae (L.) on two grain hosts (wheat and rice) comparing with the organophosphorous insecticide malathion. The results indicated that adult mortality was concentration and exposure period dependent. The most effective dust was katel-sous (Ks) powder. The next effective dust was black cement, the other tested materials recorded different percentages of cumulative mortality and could be arranged descendingly according to their efficiency as follows: sulfur flowers dust, diatomaceous earth, white cement, phosphate rock, zinc dust, animal dung ash, espidage, calcium carbonate, talc dust, sand and silica gel dust. The order of efficiency of these dusts was changed when tested on rice grain. The number of progenies descended from adults of S. oryzae that survived with the tested dusts for a period of 15 days on wheat and rice grains were influenced significantly by the type of dusts. The lowest number of progeny was produced by the survivors of sulfur dust. The highest number of progenies was recorded for the insects of control. The tested materials affected significantly the grain weight loss. Sulfur dust was the most effective protectants as it reduced the grain weight loss to the lowest value. The least effective dust in reducing grain weight loss was silica gel dust. On rice grains the percentages of grain weight loss were generally less than those of wheat grains because the rice grains were less preferable for breeding this insect, so, the numbers of produced progenies were less than those on wheat. All tested dusts attained some protection to treated grains, therefore, germination of grains treated with these dusts was generally increased.
\end{abstract}

Key words: Inert dusts, Sitophilus oryzae, wheat, rice, weight loss, germination.

\section{INTRODUCTION}

The rice weevil, Sitophilus oryzae (L) is one of the most known primary insects of cereal grains and other seeds causing a significant damage around the world. One of the main challenges facing the global grains industry is the protection of stored commodities from insect pests using safe agents. Most insect species of stored products have developed resistance to the commonly used toxic protectants and fumigants, (Subramanyam and Hagstrum, 1995).

\footnotetext{
Corresponding author: Tel. : +201119336938

E-mail address: ymanar77@yahoo.com
}

The use of inert dust to control stored grain pests is a technique with a long history and has been reviewed by many authors (Ebeling, 1971; Loschiavo, 1988; Shawir et al., 1988; Aldryhim, 1990, 1993). Inert dust, besides being very safe and presenting low toxicity to mammals, does not affect grain baking quality (Ebeling, 1971; Aldryhim, 1990).

The main aim of this work was to evaluate the efficacy of some inert dusts, that are safe, 
available and cheap in the local area such as: calcium carbonate, white cement, black cement, sand, espidage, phosphate rock, sulfur flowers, talc powder, zinc powder, animal dung ash, diatomaceous earth, silica gel and katel-sous against adults of the rice weevil, S.orzyae under laboratory conditions. The effect of the tested dusts on the number of progenies produced by the treated adults, germination percentages of treated grains and grain weight loss were also studied.

\section{MATERIALS AND METHODS}

\section{Tested Inset}

One of the most dangerous insects to cereal grains S.orzyae was chosen for this study. The cultures were started by large batches of adult initially collected from the infested stored products in warehouses at Zagazig region. The collected insects were mass reared for several generations under the conditions of $28 \pm 2{ }^{\circ} \mathrm{C}$ and $60 \pm 5 \% \mathrm{RH}$.

\section{Rearing Technique of Stock Cultures}

\section{Rearing medium}

Wheat grains variety Sakha 93 were used as a rearing host. Fresh wheat grains were firstly examined to insure that they are in a good case and free of toxic residues then they were tightly packaged in plastic bags and kept at $-13^{\circ} \mathrm{C}$, in a deep freezer for at least $48 \mathrm{hr}$. to kill any infestation that might be present. The kernels were conditioned with respect to the moisture content to be about $14 \%$ before starting the rearing or any experiment. Dry yeast was added to the wheat grains at a rate of $120 \mathrm{~g} / \mathrm{kg}$ and mixed thoroughly. The stock cultures were set up by intoroducing 500 adults (1-2 weeks old) $/ \mathrm{kg}$ on rearing medium. Glass jars of $2 \mathrm{~kg}$ capacity were half filled with the prepared medium and tightly covered with muslin cloth secured by rubber bands. Jars were kept in a rearing room adjusted at $28 \pm 2^{\circ} \mathrm{C}$ and $60 \pm 5 \%$ RH (Miller et al., 1969). The adults were permitted to oviposit in these cultures for 3 days and then removed by sifting through a No. 10 or 12 sieve. The medium with eggs was returned to the jars and the jars were kept again at the same conditions.

\section{Dusts Used}

The following materials were tested:

\section{Katel-sous (Ks)}

A dust powder formulation contains $84 \%$ calcium triphosphate plus $16 \%$ sulpher, produced by Kafer El-Zayat (KZ) Company for pesticides and chemicals, Egypt.

\section{Diatomaceous earth (DE)}

A dust powder formulation contains $97 \%$ silicon dioxide produced by Fabrique Par, Hedley Pacific Ventures LTD., Van Couver, BC. Canada.

\section{Black and white cement}

A dust powder formulation contains clay and limestone was exposed for a high degree of temperature to produce calcium silicate (Arabian Company).

\section{Talc powder (oxide magnesium, Mgo)}

A dust powder consists of magnesium silicate hydrogenated $\mathrm{Mg}_{3} \mathrm{Si}_{4} \mathrm{O}_{10}$ or $\mathrm{H}_{2} \mathrm{Mg}_{3}\left(\mathrm{Sio}_{3}\right)_{4}$. (Opal Company, Egypt).

\section{Sand dust}

A dust powder formulation contains carbonate sand is a naturally occurring granular material composed of finely divided rock and mineral particles. The second most common type of sand is calcium carbonate, for example aragonite.

\section{Calcium carbonate}

A dust powder consists of calcium carbonate $\left(\mathrm{CaCO}_{3}\right)$.

\section{Espidage}

A dust powder formulation contains of white lead $\left(\mathrm{PbcO}_{3}\right)$.

\section{Flowers of sulfur}

It is a very fine form of bright yellow sulphur powder.

\section{Zinc powder}

A dust powder consist of $\mathrm{Znc}$ or Pbs or Ags.

\section{Silica gel}

It is a granular, vitreous, porous form of silicon dioxide made synthetically from sodium 
silicate. Silica gel is tough and hard, it is more solid than common household gelis like gelatin or agar. It is naturally occurring mineral that is purified and processed into granular. As a desiccant, it has an average pore size of 2.4 nanometers and has a strong affinity for water molecules.

\section{Rock phosphate}

A dust powder of an inorganic compound and salt of phosphoric acid. Organic phosphates are esters of phosphoric acid, phosphorite, phosphate rock or rock phosphate is a nondetrital sedimentary rock which contains high amounts of phosphate bearing minerals. The phosphate content of phosphorite is at least 15 to $20 \%$; if it is assumed that the phosphate minerals in phosphorite are hydroxyapatite and fluoroapatite, phosphate minerals contain roughly $18.5 \%$ phosphorite is roughly $3.7 \%$ phosphorus by weight.

\section{Animal dung ash}

A dust powder formulation is output from burn of the animal dung. Or manure is organic matter, mostly derived from animal feces except in the case of green manure.

\section{Malathion}

0 , 0 , dimethyl phosphordithoate of diethyl mercaptosuccinate. Formulation: dust $1 \%$ Kafer El-Zayat Company (KZ). The Local Company and is processed for the preparation.

\section{Evaluation of Inert Dusts Efficiency}

To assess the insecticidal effect of the tested dusts, glass jars (200 ml capacity) were used. In each jar a quantity of uninfested $75 \mathrm{~g}$ wheat kernels were put, which were thoroughly mixed by hand shaking with the weighed amount of the tested dust to give the required rate of each dust application (1,2,3 and 4\%). All the tested materials (dusts) were sifted through a No. 25 sieve (25 mesh/inch) before using to be homogeneous and fine. Batches of 20 adults each of $S$. oryzae (1-2 week-old) were introduced into the jars (one batch for each jar).
The jars were covered with a piece of muslin cloth secured with rubber bands and kept under the conditions of $28 \pm 2^{\circ} \mathrm{C}$ and $60 \pm 5 \% \mathrm{RH}$.

The contents of the jars were sifted separately through a $2 \mathrm{~mm}$ opening sieve after 5 , 10 and 15 days post treatment to separate and remove the dead insects from the grains. The numbers of alive and dead adults were counted at the end of last interval of inspection. Percentages of mortality were accordingly determined. The contents of each jar were carefully returned again to the jars after any one of the three inspections. The jars were inspected again after 30, 45, 60 and 75 days to record the numbers of descended progenies. Three replicates were done for each rate of dust application as well as the control treatment which conducted using the same procedores without the dusts. At the end of the observation period of progenies counting (75 days), the wheat grains of each jar were weighed to determine the grain weight loss due to the insects and the germination (\%) of grains was also tested.

\section{Protection percentage}

Seventy five days after dusts application, the total number of progenies in each treatment was counted. The effectiveness of the treatments against the curculionid was calculated using the formula developed by Tabu et al. (2012).

Protection $(\%)=$

Total $F_{1}$ progeny in untreated control- total $F_{1}$ progeny in treatment $\times 100$

Total $F_{1}$ progeny in untreated control

\section{Germination Test}

Three samples of 50 grains each were taken randomly from each jar at the end of testing period (75 days) and put separately on a surface of a cotton wool layer placed in a Petri dish (10 $\mathrm{cm}$ diameter). Cotton wool layers were wet thoroughly with a tap water every day. The dishes were kept under the laboratory conditions. Daily average of temperature was recorded. Germination of grains was determined after one week of plantation by counting the viable seeds and the germination percentages were calculated for each sample according to Atwater (1980). 


\section{Toxicity of Malathion to Adult Stage}

The same procedures described before for evaluation of the inert dusts efficiency were used for evaluation the toxicity of malathion dust to $S$. oryzae adults. Serial concentrations of malathion were prepared (using talc powder as a diluent) on the base of weight of insecticide to weight of grains. Quantities of wheat grains (Sakha 93) $50 \mathrm{~g}$ each were mixed thoroughly with the suitable quantity of malathion powder. Four application rates of malathion $(8,16,24$, $32 \mathrm{ppm} \mathrm{W/W)}$ were tested. Three replicates were used for each concentration as well as for the control. Grains of the control were treated with talc powder only. Twenty adults of 1-2 weeks old were introduced to each vial, the vials were covered with muslin cloth secured with rubber bands and kept at $28 \pm 2{ }^{\circ} \mathrm{C}$ and $60 \pm 5 \%$ $\mathrm{RH}$. Mortality counts were recorded after the periods of 5,10,15 days and the cumulative mortality percentages were recorded. The mortality (\%) were corrected according to Abbott's formula (Abbott, 1925).

The different aspects which were studied in case of the inert dusts such as numbers of progenies after 75 days, grain weight loss and grain germination (\%) were also studied for malathion treatment.

Note: The above mentioned experiments carried out on wheat grains were conducted exactly on rough rice grains.

Data obtained of cumulative (\%) mortality after 15 days, total numbers of progenies after 75 days, grain weight loss and germination (\%) for each tested dust as well as the control were statistically analyzed using analysis of variance (F. test). Significant differences between means of all treatments were tested using the least significant difference method (LSD) (Gand, 2001).

\section{RESULTS AND DISCUSSION}

\section{Efficiency of Dusts}

The cumulative mortality percentages of $S$. oryzae adults exposed to wheat grains treated separately with different dusts (13 dusts) at four rates of application for each dust after 15 days of exposure were calculated (Table 1). It seems generally that the tested materials were effective and differed significantly from each other at any of the tested rates of application (1, 2, 3 and 4\%) against the tested insect. The most effective dust was Katel-sous (Ks) powder inducing $91.66 \%$ as a general mean of cumulative percent mortality. The next effective dust was black cement recording 90\% mortality. The other tested materials recorded different percentages of cumulative mortality and could be arranged descendingly according their efficiency as follows: sulfur flowers $(88.25 \%)$, diatomaceous earth (DE) (86.66\%), white cement $(71.66 \%)$, phosphate rock $(70.41 \%)$, zinc $(68.75 \%)$, animal dung ash $(65.41 \%)$, espidage $(63.75 \%)$, calcium carbonate $(60 \%)$, talc $(57.5 \%)$, sand $(50.83 \%)$ and silica gel (40\%). The order of efficiency of these dusts against adults of $S$. oryzae was changed when tested on rice grains (Table 1). The most effective dust on rice grains was white cement recording the highest percentage of cumulative mortality $(97.08 \%)$ as a general mean of mortality after 15 days of exposure). This dust was the fifth in order of toxicity when tested on wheat grains, thus the type of grains had a clear effect on the efficiency of the tested dusts against the tested insect. It was observed generally that, most dusts were more effective when used on rice grains than on wheat grains, this may be attributed to the amount of dust that in contact to the surface of rice grains was so much. Some of the tested dusts recorded approximately the same efficacy on both hosts such as black cement, sulfur dust, talc powder and katel-sous. However, talk powder recorded the lowest effect on rice grain.

In conclusion, Katel-sous and black cement are promising as protectants against this insect on wheat grains, while white cement and diatomaceous earth are promising as protectants against this insect on rice.

Data in Table 1 show also that there are significant differences between the rates of dusts application; percentages of insect mortality increased as the rate of dust application increased on both hosts. The highest percentages of insect mortality were recorded for the highest rate of application (4\%). 
Table 1. Efficacy of different inert dusts at four rates of application against Sitophilus oryzae adults at $30^{\circ} \mathrm{C}$ and $60 \pm 5 \% \mathrm{RH}$ on two hosts

\begin{tabular}{|c|c|c|c|c|c|c|c|c|c|c|}
\hline \multirow{4}{*}{ Tested dust } & \multicolumn{5}{|c|}{ Wheat grains } & \multicolumn{5}{|c|}{ Rice grains } \\
\hline & \multicolumn{5}{|c|}{$\begin{array}{c}\text { Cumulative mortality (\%) after } 15 \\
\text { days of treatment }\end{array}$} & \multicolumn{5}{|c|}{$\begin{array}{c}\text { Cumulative mortality (\%) after } 15 \\
\text { days of treatment }\end{array}$} \\
\hline & \multicolumn{5}{|c|}{ Rate of application } & \multicolumn{5}{|c|}{ Rate of application } \\
\hline & $1 \%$ & $2 \%$ & $3 \%$ & $4 \%$ & $\begin{array}{c}\text { General } \\
\text { means }\end{array}$ & $1 \%$ & $2 \%$ & $3 \%$ & $4 \%$ & $\begin{array}{c}\text { General } \\
\text { means }\end{array}$ \\
\hline Calcium carbonate $\left(\mathrm{Caco}_{3}\right)$ & 18.33 & 56.67 & 73.33 & 91.67 & 60.00 & 61.67 & 66.67 & 70.00 & 83.33 & 70.41 \\
\hline White cement & 56.67 & 61.67 & 73.33 & 95.00 & 71.66 & 91.67 & 98.33 & 98.33 & 100.00 & 97.08 \\
\hline Black cement & 61.67 & 98.33 & 100.00 & 100.00 & 90.00 & 86.67 & 91.67 & 95.00 & 100.00 & 93.33 \\
\hline Sand & 13.33 & 23.33 & 75.00 & 91.67 & 50.83 & 56.67 & 65.00 & 73.33 & 91.67 & 71.66 \\
\hline Espidage & 20.00 & 55.00 & 88.33 & 91.67 & 63.75 & 76.67 & 80.00 & 86.67 & 98.33 & 85.41 \\
\hline Phosphate rock & 50.00 & 60.00 & 75.00 & 96.67 & 70.41 & 60.00 & 63.33 & 83.33 & 100.00 & 76.66 \\
\hline Flowers of sulfur & 80.00 & 83.00 & 90.00 & 100.00 & 88.25 & 70.00 & 80.00 & 95.00 & 98.33 & 85.83 \\
\hline Talc ( Mgo) & 36.67 & 60.00 & 66.67 & 66.67 & 57.50 & 41.67 & 45.00 & 65.00 & 83.33 & 58.75 \\
\hline Animal dung ash & 21.67 & 48.33 & 93.33 & 98.33 & 65.41 & 88.33 & 91.67 & 96.67 & 100.00 & 94.16 \\
\hline Zinc & 48.33 & 51.67 & 76.67 & 98.33 & 68.75 & 75.00 & 85.00 & 86.67 & 96.67 & 85.83 \\
\hline Diatomaceous earth (DE) & 78.33 & 81.67 & 88.33 & 98.33 & 86.66 & 91.67 & 93.33 & 98.33 & 100.00 & 95.83 \\
\hline Silica gel & 30.00 & 31.67 & 35.00 & 63.33 & 40.00 & 66.67 & 68.33 & 75.00 & 83.33 & 73.33 \\
\hline Katel-sous (Ks) & 80.00 & 91.67 & 95.00 & 100.00 & 91.66 & 85.00 & 88.33 & 96.67 & 100.00 & 92.50 \\
\hline General means & 45.76 & 61.77 & 79.23 & 91.66 & -- & 73.20 & 78.20 & 86.15 & 94.99 & -- \\
\hline
\end{tabular}

$\mathrm{LSD}_{0.05}$ level for dusts $=10.36$

$\mathrm{LSD}_{0.05}$ level for dusts $=7.52$

$\mathrm{LSD}_{0.05}$ level for concent. $=2.82$

$\mathrm{LSD}_{0.05}$ level for concent. $=4.15$

$\mathrm{LSD}_{0.05}$ level for dusts $\times$ concent. $=20.72$

$\mathrm{LSD}_{0.05}$ level for dusts $\times$ concent. $=15.06$

As for the interaction effects of dusts $\mathrm{x}$ rates of application on the cumulative percentages of insect mortality on both hosts are shown in Table 1. The results show that the higher rates of application of some dusts $\left(2^{\text {nd }}, 3^{\text {rd }}\right.$ and $\left.4^{\text {th }}\right)$ did not differ significantly from each other, while the lower one was differed significantly such as black cement on wheat. In some cases the first three rates (1, 2 and $3 \%)$ did not differ significantly from each other but differed significantly than the highest rate (4\%) (Table 1).

The present results agree with those recorded by: Strong and Sbur (1963) who tested in the laboratory the effectiveness of diatomaceous earth at the rates of 4,6 and 8 Ibs. per ton of grains against $S$. oryzae, $S$. granaries, Rhizopertha dominica (F.), Tribolium confusum Duv., Oryzaephilus surinamensis (L.) and Cryptolestes pusillus (Schonhen) under constant conditions of $80 \pm 1{ }^{\circ} \mathrm{F}$ and $60 \pm 5 \%$ RH. They found that $4 \mathrm{Ibs}$. of diatomaceous earth per ton of grains would prevent infestation for 6 months and still effective when the experiment was terminated 12 months after initial exposure to insects. Also, McGaughey (1972) recorded that a diatomaceous earth produced $100 \%$ mortality of $S$. oryzae and $T$. confusum when exposed for 21 days to rough rice treated with this material at the dosages of 1.75 and $3.5 \mathrm{~g} / \mathrm{kg}$, respectively. 
Javaid and Ramatlakapela (1995) tested the effectiveness of ash and sand against $C$. maculatus in cowpea seeds. They showed that cow dung ash at high doses was statistically similar to the effectiveness of malathion dust in some parameters. El-Lakwah et al., (1996) studied in the laboratory the effect of cotton stem and animal dung ashes on some stored product insects, namely; $S$. oryzae, $R$. dominica, $T$. castaneum, compared to Katel-sous. They reported that adult mortalities increased with increasing concentration and exposure period. Complete mortalities for various insect species after 3 weeks from treatment with animal dung ash at varying rates $(1-4 \%)$ and Katel-sous at $(1 \%)$, were recorded. Several proposed mode of action for inert dusts have been extended by various researchers. They are: inert dusts block spiracles and insects die from asphyxiation, dusts lodging between cuticular segments increase water loss through abrasion of the cuticle and dusts absorb water from the insect's cuticle. Insects and mites die from ingesting the dust particles and dusts absorb the epicuticular lipids of arthropods leading to excessive water loss through the cuticle. Death in arthropods is attributed to this excessive water loss or desiccation.

The most widely accepted explanation for the action of inert dusts is that they kill arthropods by removing or absorbing the epicuticular lipid layers causing excessive water loss through the cuticle (Zacher and Kuhike, 1931; Zacher, 1937 a,b; Chiu, 1939 a,b; Wigglesworth, 1944, 1945, 1947; David and Gardiner, 1950; Nair, 1957 ; Tarshis, 1959, 1960, 1961).

The rate at which cuticular waxes are absorbed by inert dusts may vary with the type of waxes, temperature, relative humidity, oil absorption capability of the inert dust, and dust particle size distribution. Also, the rate of water loss through cuticle of a given insect/mite species varies with temperature (Edney, 1977; Johnson et al., 2014; Kabir and Wulgo, 2014; Korunic et al., 2014; Zhang et al., 2014). Ebeling (1971) concluded that the insecticidal efficacy of inert dusts primarily depends on the pore size ( $>20$ angstroms), large specific surface area and the oil absorption capability.

\section{Number of Progenies Descended from Dust Survivors}

Data presented in Table 2 show generally that number of progenies descended from adults of $S$. oryzae that survived the tested dusts for a period of 15 days on wheat grains were influenced significantly by the type of dust. The lowest number of progenies (51.73 progenies) was produced by the survivors of flowers of sulfur dust, in other words, sulfur dust was the most effective in reducing the number of progenies. Diatomaceous earth, zinc and calcium carbonate dusts followed sulfur dust in their effects in reducing the numbers of progenies recording 55.06, 59.31 and 63.91 progenies, respectively without significant differences between them. The highest number of progenies (194.60 progenies) was recorded for the insects of control followed in descending order by silica gel (157.65), talc powder (153.12), espidage (132.65) and sand dust (119.97 progenies). The other dusts produced intermediate numbers of progenies.

It should be mentioned that low numbers of produced progenies may be attributed to the direct effect of the dusts on the mortality of insect parents exposed to the dusts, as the mortality of dust-exposed insects (parents) increased the number of progenies decreased.

As regards to the effect of dust application rate on the number of progenies, it was observed generally that numbers of progenies were significantly decreased as the rates of dust application increased recording 121.52 progenies for $1 \%$ and decreased to 76.95 progenies for $4 \%$ as general means, with significant differences between the four rates of application.

As the interaction effects of dusts $\mathrm{x}$ rates of application on the number of progenies, it was observed that as the rate of dust application increased the number of progenies decreased for all the tested dusts (Table 2).

In case of rice grains, the numbers of progenies were clearly decreased comparing with wheat grains. This may be attributed to the higher mortality of dust-exposed adults (parents) on rice grains than on wheat grains, therefore, the number of survived adults (parents) was low, 
Zagazig J. Agric. Res., Vol. 44 No. (1) 2017

Table 2. Numbers of progenies descended from Sitophilus oryzae adults that survived after exposure to the inert dusts at four rates of application for two weeks on two hosts at $30^{\circ} \mathrm{C}$ and $60 \pm 5 \%$ RH

\begin{tabular}{|c|c|c|c|c|c|c|c|c|c|c|c|}
\hline \multirow[t]{4}{*}{ Tested dust } & \multicolumn{5}{|c|}{ Wheat grains } & \multicolumn{6}{|c|}{ Rice grains } \\
\hline & \multicolumn{5}{|c|}{ Total No. of progenies } & \multicolumn{6}{|c|}{ Total No. of progenies } \\
\hline & \multicolumn{5}{|c|}{ Rates of application } & \multicolumn{6}{|c|}{ Rates of application } \\
\hline & $2 \%$ & $3 \%$ & $4 \%$ & $\begin{array}{c}\text { General } \\
\text { means }\end{array}$ & $\begin{array}{l}\text { Protection } \\
(\%)\end{array}$ & $1 \%$ & $2 \%$ & $3 \%$ & $4 \%$ & $\begin{array}{c}\text { General } \\
\text { means }\end{array}$ & $\begin{array}{c}\text { Protection } \\
(\%)\end{array}$ \\
\hline Calcium carbonate $\left(\mathrm{Caco}_{3}\right)$ & $69.33 \quad 68.67$ & 64.00 & 53.67 & 63.91 & 67.16 & 17.67 & 14.67 & 13.33 & 11.00 & 14.16 & 38.39 \\
\hline White cement & 127.00104 .00 & 76.00 & 54.66 & 90.41 & 53.53 & 19.33 & 19.00 & 17.67 & 14.33 & 17.58 & 23.56 \\
\hline Black cement & $114.00 \quad 92.33$ & 75.00 & 44.66 & 81.49 & 58.12 & 13.67 & 13.33 & 12.00 & 10.33 & 12.33 & 46.39 \\
\hline Sand & 126.60124 .00 & 118.30 & 111.00 & 119.97 & 38.35 & 17.67 & 15.67 & 13.33 & 10.00 & 14.16 & 38.43 \\
\hline Espidage & 159.30158 .30 & 128.00 & 85.00 & 132.65 & 31.83 & 12.00 & 11.00 & 10.00 & 9.33 & 10.58 & 54.00 \\
\hline Phosphate rock & $77.00 \quad 80.00$ & 69.33 & 58.33 & 71.16 & 36.43 & 14.67 & 14.33 & 13.30 & 11.00 & 13.32 & 42.08 \\
\hline Flowers of sulfur & $81.00 \quad 55.30$ & 49.30 & 21.33 & 51.73 & 73.41 & 11.00 & 10.67 & 10.00 & 7.67 & 9.83 & 57.26 \\
\hline Talc dust (Mgo) & 188.30152 .00 & 147.60 & 124.60 & 153.12 & 21.31 & 20.67 & 19.33 & 18.67 & 13.33 & 18.00 & 21.73 \\
\hline Animal dung ash & 127.00121 .67 & 95.30 & 77.30 & 105.31 & 45.87 & 13.00 & 14.67 & 12.33 & 9.00 & 12.25 & 44.21 \\
\hline Zinc & $80.67 \quad 60.33$ & 50.67 & 45.60 & 59.31 & 69.55 & 17.67 & 14.66 & 13.33 & 10.33 & 13.99 & 39.17 \\
\hline Diatomaceous earth (DE) & $59.33 \quad 65.33$ & 60.00 & 35.60 & 55.06 & 71.70 & 18.33 & 16.00 & 15.00 & 14.33 & 15.91 & 30.82 \\
\hline Silica gel & 195.60192 .00 & 130.0 & 113.00 & 157.65 & 18.98 & 14.33 & 13.00 & 12.33 & 9.00 & 12.16 & 47.13 \\
\hline Katel-sous (Ks) & 101.6098 .00 & 87.30 & 58.00 & 86.22 & 55.68 & 13.33 & 12.00 & 10.00 & 8.67 & 11.00 & 52.17 \\
\hline Control & & 194.6 & & & -- & & & 23.00 & & & - \\
\hline General means & 121.52111 .89 & 96.10 & 76.95 & -- & & 16.16 & 15.09 & 13.87 & 11.52 & -- & \\
\hline $\begin{array}{l}\mathrm{LSD}_{0.05} \text { level for dusts }= \\
\mathrm{LSD}_{0.05} \text { level for concent } \\
\mathrm{LSD}_{0.05} \text { level for dust } \times \text { co }\end{array}$ & $\begin{array}{l}14.67 \\
=7.84 \mathrm{~s} \\
\text { ncent. }=29.36\end{array}$ & & & $\begin{array}{l}\operatorname{LSD}_{0.0} \\
\operatorname{LSD}_{0.0} \\
\operatorname{LSD}_{0.0}\end{array}$ & $\begin{array}{l}{ }_{5} \text { level fo } \\
5 \text { level fo } \\
{ }_{5} \text { level fo }\end{array}$ & $\begin{array}{l}\text { dusts }= \\
\text { concen } \\
\text { dust } \times \text { c }\end{array}$ & $\begin{array}{l}=1.87 \\
\text { ht. }=0.9 \\
\text { oncent }\end{array}$ & $\begin{array}{l}97 \\
\text { t. }=3 .\end{array}$ & & & \\
\hline
\end{tabular}

so, produced less progenies. Rice grains are considered less preferable host for this insect than wheat grains, therefore, this insects bred weakly on rice grains (Table 2).

El-Lakwah et al. (1996) reported that animal dung ash was more effective than cotton stem ash and gave at the highest rate (4\%) nearly similar reduction in $\mathrm{F}_{1}$ progeny as katel-sous at the recommended concentration (1\%). Mewis and Ulrichs (2002) mentioned that diatomaceous earth (DE) at 1 and $2 \mathrm{~g} / \mathrm{kg}$ rice reduced population growth of $T$. castanum after 42 days. They added that (DE) at $0.5 \mathrm{~g} / \mathrm{kg}$ rice increased the insect mortality of $T$. castanum but did not stop population growth.
Kabir et al. (2012) evaluated the efficacy of raw diatomaceous earth (DE) against $R$. dominica and $T$. castaneum in maize, sorghum and wheat. Significant differences $(\mathrm{P}<0.05)$ in adult mortality were noted between dose rates and exposure periods on all grains. Increase in dose rate and exposure period resulted in higher adult mortality and progeny suppression.

\section{Grain Weight Loss}

Results respecting grain weight loss due to the dust treated adults and their progenies are presented in Table 3. The tested materials affected significantly the grain weight loss, flowers of sulfur dust was the most effective 
protectant as it reduced the grain weight loss to the lowest value $(16.75 \%)$ followed by $\mathrm{Ks}$ (26.95\%), phosphate rock $(27.80 \%)$, espidage (28.15\%), white cement dust (29.25\%), without significant differences between the last four dust treatments, the effect of the dust on reducing grain weight loss may be mainly correlated with the effect of the dust on adult mortality and hence the number of produced progenies. On the other hand, the effects of each dust on adults activity and feeding behavior may be affected their food consumption.

Data in Table 3 show also that higher rates of dust application reduced significantly grain weight loss than the lower rates of application. This observation was found for all tested rates of each dust on both hosts (Table 3 ).

On rice grains, the percentages of grain weight loss were generally less than that of wheat grains because rice grains were less preferable host for breeding of this insect, so, the numbers of produced progenies were less than that on wheat. However, sulfur flowers dust was the most effective dust since it caused the lowest percent of grain weight loss on both hosts $(16.75 \%$ on wheat and $4.47 \%$ on rice) while silica gel was the lowest dust $\left(13^{\text {th }}\right)$ in order of efficiency on wheat while it was the twelfth in order of efficiency on rice grains causing $(14.82 \%)$ weight loss. Control grain weight loss recorded the highest percentage of grain weight loss for both hosts $(43.30 \%$ for wheat and $25.60 \%$ for rice).

Mugo et al. (2015) admixed diatomaceous earth and wood ash with $100 \mathrm{~g}$ of maize or wheat in ventilated glass jars. Dusts effectively controlled S. zeamais with $95 \%-100 \%$ mortality. A delayed effect appeared to contribute to the higher damage inflicted, hence more weight loss was expected.

\section{Germination of Wheat and Rice Grains}

Germination of wheat and rice grains treated with the tested dusts and artificially infested with adults of $S$. oryzae was influenced significantly by some dusts and not influenced statistically by the other ones. Germination of both grain hosts was differed from one treatment to another without a clear trend, but germination of control grains was generally reduced than germination of all dust treatments. The results showed that all tested dust treatments provided some protection to treated grains, therefore, germination of grains treated with dusts was increased specially in case of wheat grains. In case of rice grains the tested dusts increased germination percentages than the control in most cases (Table 4).

It is difficult to interpret the results of germination percentages. There is no clear trend for germination percentages, it is not generally correlated with the cumulative percentage mortality of adults and their progenies as a cause, it may be correlated to the type of damage that caused in grains due to the insect adults and their progenies. It was expected that as the cumulative mortality of insect adults increased; their progenies were decreased and therefore, the germination percentages increased. This expectation or this trend is not really occurred. The germination percentages of grains were not correlated with one obvious factor.

Germination percentages of grains of both hosts took a clear trend in relation to the rate of dust application (Table 4). As the rate of dust application increased the percentages of grains germination increased. This result was recorded for all tested dusts on both tested hosts. However, rice grains were less attractive to the tested insect, and the insects were poorly bred in this host, so, germination of this host was much more the germination of wheat grains.

Tabu et al. (2012) evaluated the efficacy of some botanical inert materials and edible oils against bean beetle, Callosobruchus chinensis L. in stored chickpea. The botanical inert materials and edible seed oils caused high adult mortality, reduced eggs laid, reduced $F_{1}$ progeny emergence, low seed damage and low seed weight loss without affecting seed germination in stored chickpea seeds.

\section{Efficiency of Malathion dust (1\%)}

The effect of malathion dust $1 \%$ on adults mortality, total number of progeny after 75 days, grain germination (\%) and weight loss of wheat and rice grains are presented in Table 5. The results indicate clearly that cumulative mortality was increased by increasing the rate of application. At the rate of $8 \mathrm{ppm}$, mortality was $78.33 \% 15$ days after treatment and increased to $100 \%$ at the rate of $32 \mathrm{ppm}$. 
Zagazig J. Agric. Res., Vol. 44 No. (1) 2017

Table 3. Grain weight loss due to Sitophilus oryzae adults and their progenies reared on two host grains treated with different inert dusts at four rates of application at $30^{\circ} \mathrm{C}$ and $60 \pm 5 \%$ RH

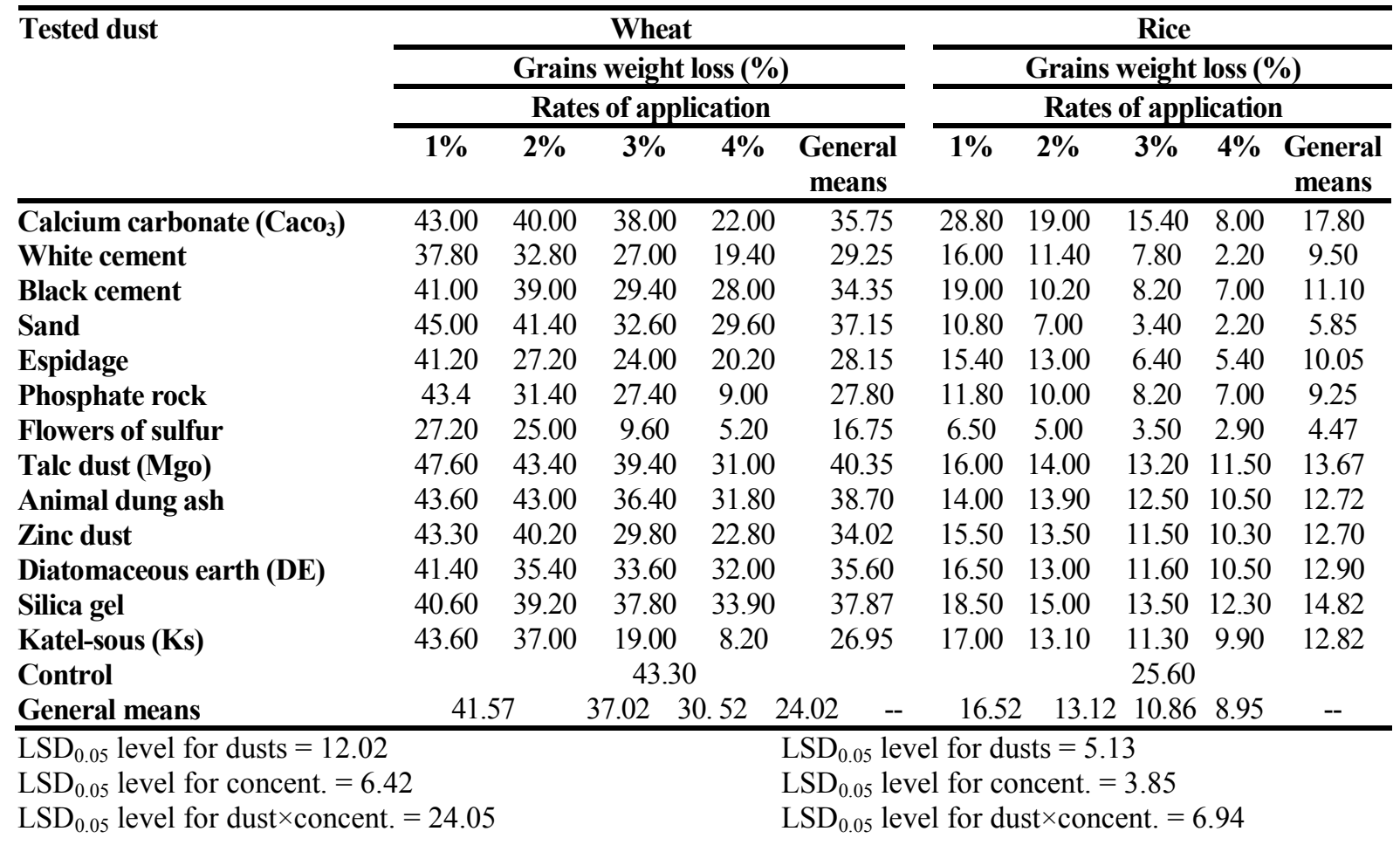

Table 4. Effect of different inert dusts at four rates of application on germination (\%) of wheat and rice grains artificially infested with Sitophilus oryzae at $30^{\circ} \mathrm{C}$ and $60 \pm 5 \% \mathrm{RH}$

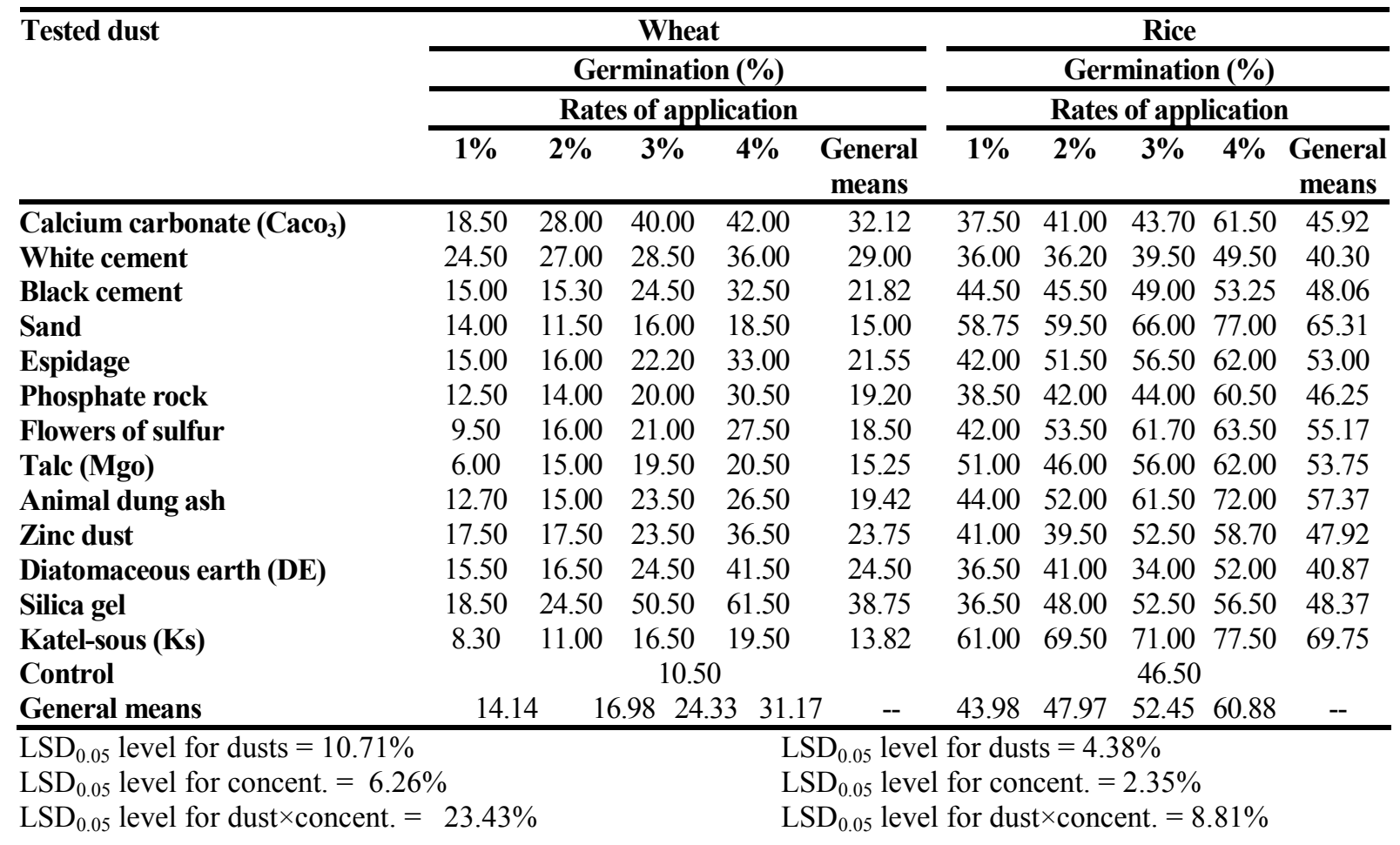


Table 5. Effect of malathion dust tested at different rates of application against Sitophilus oryzae adults on two hosts at $28^{\circ} \mathrm{C}$ and $60 \pm 5 \% \mathrm{RH}$

\begin{tabular}{|c|c|c|c|c|c|c|c|c|}
\hline \multirow{2}{*}{$\begin{array}{c}\text { Concentration } \\
(\mathrm{ppm})\end{array}$} & \multicolumn{4}{|c|}{ Wheat grains } & \multicolumn{4}{|c|}{ Rice grains } \\
\hline & $\begin{array}{c}\text { Cumulative } \\
\text { mortality (\%) } \\
\text { (15 days post- } \\
\text { treatment) }\end{array}$ & $\begin{array}{l}\text { Total No. of } \\
\text { progenies } \\
\text { (75 days post- } \\
\text { treatment) }\end{array}$ & $\begin{array}{c}\text { Germination } \\
(\%)\end{array}$ & $\begin{array}{c}\text { Grain } \\
\text { weight } \\
\text { loss } \\
(\%)\end{array}$ & $\begin{array}{c}\text { Cumulative } \\
\text { mortality (\%) } \\
\text { (15 day post } \\
\text { treatment) }\end{array}$ & $\begin{array}{l}\text { Total No. of } \\
\text { progenies } \\
\text { (75 days post- } \\
\text { treatment) }\end{array}$ & $\begin{array}{c}\text { Germination } \\
(\%)\end{array}$ & $\begin{array}{c}\text { Grain } \\
\text { weight } \\
\text { loss } \\
(\%)\end{array}$ \\
\hline 8 & 78.33 & 126.66 & 11.50 & 36.80 & 71.67 & 17.60 & 78.50 & 9.60 \\
\hline 16 & 81.67 & 119.00 & 25.50 & 28.60 & 78.33 & 14.60 & 81.00 & 8.90 \\
\hline 24 & 96.30 & 52.00 & 43.50 & 17.40 & 80.00 & 13.30 & 84.50 & 8.60 \\
\hline 32 & 100.00 & 32.33 & 62.82 & 8.40 & 88.33 & 11.00 & 86.00 & 5.40 \\
\hline Control & 5.42 & 175.25 & 6.12 & 50.25 & 5.00 & 21.91 & 80.75 & 9.50 \\
\hline $\mathbf{L S D}_{0.05}$ & 2.51 & 14.61 & 6.32 & 7.77 & 5.90 & 3.56 & 2.74 & 0.67 \\
\hline
\end{tabular}

Total progenies decreased when the concentration of malation increased. At $8 \mathrm{ppm}$, $\mathrm{F}_{1}$-progeny No. was 126.66 after 75 days of treatment and decreased to 32.33 progenies at 32 ppm. The germination (\%) increased when the concentration of malathion increased, at $8 \mathrm{ppm}$ the germination percentage was $11.50 \%$ and increased to $62.82 \%$ at $32 \mathrm{ppm}$. Weight loss of wheat grain decreased when the concentration of malathion increased. At $8 \mathrm{ppm}$, the wheat grain loss was and $36.80 \%$ decreased to $8.40 \%$ at 32 ppm. In case of rice grains, similar results were found; mortality (\%) increased by increasing the malathion concentration while total No. of progenies after 75 days post-treatment decreased from 17.60 at $8 \mathrm{ppm}$ to 11.00 individuals at 32 ppm. Germination (\%) increased from 78.50 at 8 ppm to $86.0 \%$ at $32 \mathrm{ppm}$. Weight loss of rice grains decreased when the rate of malathion application increased. There is no significant difference between $8 \mathrm{ppm}$ concentration and the control (9.60 and $9.50 \%$, respectively).

Similar results were obtained by some others such as Waters (1959) who recorded that malathion applied at $2 \mathrm{ppm}$ to wheat caused $99 \%$ mortality of the rusty grain beetle, Laemphloeus ferrugineus (Steph.). Karmer et al. (1985) investigated the effect of malathion (10 ppm) as wheat grain protectant in small bins against infestation of $S$. oryzae, $T$. confusum and Plodia interpunctella (Hübner) for two grain storage seasons in Kansas. They found that malathion at $10 \mathrm{ppm}$ was inadequate for controlling the moth and beetle species. Bhuigah (1993) studied the effect of fenitrothion (as Edthion, Sovathion and Sumithion) and malathion (as Syfanon and Fyfanon) as sack treatments against $S$. oryzae in stored wheat in Bangladesh during July to December 1991 . He noticed that all the tested insecticides and dosages tested induced significant reduction in numbers of the pest. The insecticides kept the grain weight loss down to $14.05-23.13 \%$ as compared with the control (45.79\%).

\section{REFERENCES}

Abbott, W.S. (1925). A method of computing the effectiveness of an insecticides. J. Econ. Entomol., 18 (3): 265-267.

Aldryhim, Y.N. (1990). Efficacy of the amorphous silica dust, Dryacide, against Tribolium confusum Duv. and Sitophilus granaries (L.) (Coleoptera: Tenebrionidae and Curculionidae). J. Stored Prod. Res., 26 : 207-210.

Aldryhim, Y.N. (1993). Combination of classes of wheat and environmental factors affecting the efficacy of amorphous silica dust, Dryacide, against Rhyzopertha dominica (F.). J. Stored Prod. Res., 29 : 271-275.

Atwater, (1980). Association of Official Seeds Analysis. Seed Sci. and Technol., 8 : 523-573. 
Bhuigah, M.I.M. (1993). Evaluation of insecticides in sacks for the control of Sitophilus oryzae (L.) in stored wheat. Bangladesh J. Zool., 21 (2): 67-75.

Chiu, S.F. (1939a). Toxicity studies of so-called "inert" materials with the bean weevil, Acanthoscelides obtectus (Say). J. Econ. Entomol., 32 : 240-248.

Chiu, S.F. (1939b). Toxicity studies of so-called "inert" materials with the rice weevil and the granary weevil. J. Econ. Entomol., 32:810821.

David, W.A.L. and B.O.C. Gardiner (1950). Factors influencing the action of dust insecticides. Bull. Entomol. Res., 41 : 1-61.

Ebeling, W. (1971): Sorptive dusts for pest control. Ann. Rev. Entomol., 16:123-158.

Edney, E.B. (1977). Water Balance in Land Arthropods. Springer-Verlag, Berlin.

El-Lakwah, F.A., R.A. Mohamed and Z.A. Halawa (1996). Effect of cotton stem and animal dung ashes as grain protectants on some stored product insects. Ann. Agric. Sci., Moshtohor, 34 (4): 1861-1867.

Gand, S.C. (2001). Statistics for Toxicologist. In Principles and Methods of Toxicology. Ed. by Hayes, WA $4^{\text {th }}$ Ed., Taylor and Francis, USA, 285-264.

Javaid, I. and K. Ramatlakapela (1995). The managemant of cowpea weevils (Callosobruchus maculatus) (F.) in cowpea seeds by using ash and sand. J. Sustain Able Agric., 6 (2/3): 147-154.

Johnson, L., C. Kumar, J. Hayles and D. Losic (2014). Grain protection with admixed inert dusts (diatomaceous earth): exploring key parameters for improving the efficacy of wet application. $11^{\text {th }}$ Int. Working Conf. on Stored Prod. Prot.: 828-840, Thailand, 24-28 November.

Kabir, B.G.J. and M.A. Wulgo (2014). Efficacy of four diatomaceous earth formulations against Callosobruchus maculatus (F.) (Coleoptera: Bruchidae) on cowpea. $11^{\text {th }}$ Int. Working Conf. on Stored Prod. Prot.: 798806. Thailand, 24-28 November.

Kabir, B.G.J., M. Lawan and H.T. Abdutrahman (2012). Effects of raw diatomaceous earth
(DE) on mortality and progeny development of Rhyzopertha dominica Fab. (Coleoptera: Bostrichidae) and Tribolium castaneum Herbst (Coleoptera: Tenebrionidae) on the cereal grains. Acad. Entomol., 5 (1): 16-21.

Karmer, K.J., L.H. Hendricks, J.H. Wojciak and J. Fyler (1985). Evaluation of fenoxycarb, Bacillus thuringiensis, and malathion as grain protectants in small bins. J. Econ. Entomol., $78: 632-636$.

Korunic, Z., R. Almasi, G. Andric, P. Kljajic, P.G. Fields, W. Wakil and M. Ziaee (2014). Variation in the susceptibility of stored product insects from five locations to two diatomaceous earth and botanical based formulatinos. $11^{\text {th }}$ Int. Working Conf. Stored Prod. Protec.: 808-818, Thailand, 24-28 November.

Loschiavo, S.R. (1988). Availability of food as a factor in effectiveness of a silica aerogel against the merchant grain beetle (Coleoptera: Cucujidae). J. Econ. Entomol., $81: 1237-1240$.

McGaughey, W.M.H. (1972): Diatomaceous earth for confused flour beetle and rice weevil control in rough, brown and milled rice. J. Econ. Entomol., 65 (5): 1427-1428.

Mewis, V.I. and C. Ulrichs (2002): Treatment of rice with diatomaceous earth and effects on the mortality of the red flour beetle, Tribolium castaneum (Herbst). Anzeigerfur Schading Skunde, 74 (1): 13-16.

Miller, A., R. Philips and L.D. Cline (1969). Rearing Manual for Stored Product Insects used by USDA Stored Product Insects, Research and Development Laboratory, SAVANNAH, Georgia.

Mugo, N.C., M.J. Nderi and M. Kimondo (2015). effect of diatomaceous earths on mortality, progeny and weight loss caused by three primary pests of maize and wheat in Kenya. Inter. J. Sci., Tech. and Soc., 3 (3): 76-82.

Nair, M.R.G.K. (1957). Structure of waterproofing epicuticular layers in insects in relation to inert dust action. Indian J. Entomol., 10: 37 - 49. 
Shawir, M., G.N.J. Le Patourel and F.I. Moustafa (1988). Amorphous silica as an additive to dust formulations of insecticides for stored grain pest control. J. Stored Prod. Res., 24 : 123-130.

Strong, R.G. and D.E. Sbur (1963). Protection of wheat seed with diatomaceous earth, J. Econ. Entomol., 56 (3): 372-374.

Subramanyam, B.H. and D. Hagstrum (1995). Resistance Measurement and Management. In: Subramanyam, Bh., Haastrum, D. (Eds), Integrated Management of Insects in Stored Products. Marcel Dekker, Inc., New Yourk, 331-398.

Tabu, D., T. Selvaraj, S.K. Singh and N. Mulugeta (2012). Management of Adzuki bean beetle (Callosobruchus chinensis L.) using some botanical S, inert materials and edible oils in stored chickpea. J. Agric. Tech., 8 (3): 881-902.

Tarshis, I.B. (1959). V.C.L.A. tests with desiccant dusts for roach control. Pest Control, 27: $16-32$.

Tarshis, I.B. (1960). Control of the snake mite (Ophionyssus natricis), other mites and certain insects with the sorptire dust, SG-67. J. Econ. Entomol., 53 : 903 - 908.

Tarshis, I.B. (1961). Laboratory and field evaluation studies with sorptive dusts for the control of arthropods affecting man and animal. Exptl. Parasitol., $11: 10$ - 13.
Waters, F.L. (1959). Effects of grain moisture content on residual toxicity and repellency of malathion. J. Econ. Entomol., 52 : 131-134.

Wigglesworth, V.B. (1944). Action of Inert Dusts on Insects. Nature (London), $153: 493$ $-494$.

Wigglesworth, V.B. (1945). Transpiration through the cuticle of insects. J. Exptl. Biol., $21: 97-114$.

Wigglesworth, V.B. (1947). The site of action of inert dusts on certain beetles infesting stored products. Proc. Rony. Entomol. Soc. (London), Ser. A, 22: 65-69.

Zacher, F. (1937a). Eine neue Gruppe von Insektiziden. C.R. du XII Congress, Tntern. De Zool. Lisbonne, 1935: 2336-2340.

Zacher, F. (1937b): Neue Untersuchungen über die einwirkung ober flachenäktiver pulver auf inseckten. Zool Anzeiger 10 (Supplemantband): $264-271$.

Zacher, F. and G. Kuhike (1931). Untersuchungen über die insecktizide wirkung von oxyden und karbonaten. Arb. Aus. Biol., Reichsans., $18: 201-231$.

Zhang, T., Y. Cao, Y.Y. Li, Y.S. Gao and J.H. Feng (2014). Food-grade inert dust as structural treatment against insect pests. $11^{\text {th }}$ Int. Working Conf. Stored Prod. Protec., Thailand, 24-28 November: 883-884. 


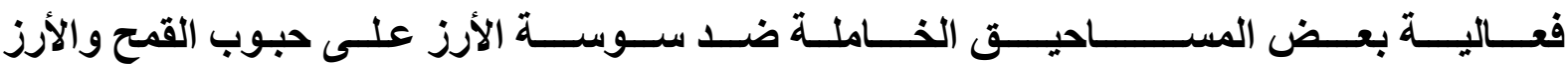

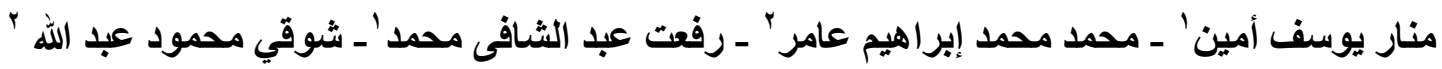

$$
\begin{aligned}
& \text { 1 ـ ـ معهد بحوث وقاية النباتات ـ مركز البحوث الزر اعية ـ دقي ـ جيزة ـ مصر }
\end{aligned}
$$

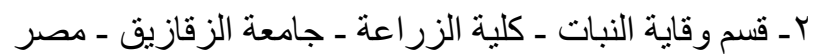

تهدف هذه الدراسة إلى تقييم فعالية بعض المساحيق الخاملة الآمنة والمنوفرة في البيئة المحلية وهى كربونات

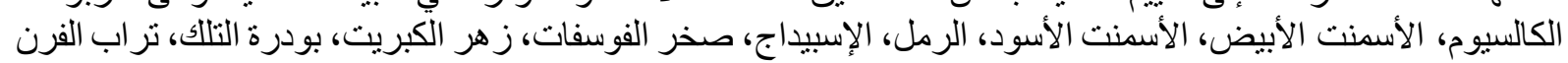

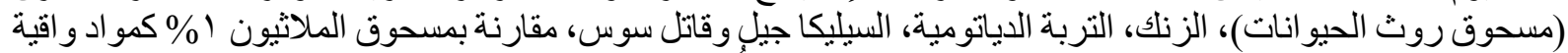

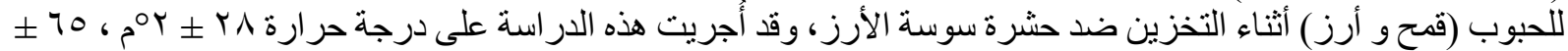

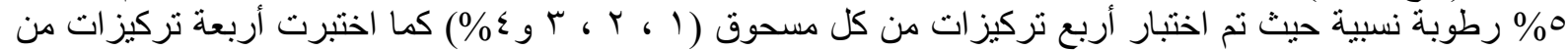

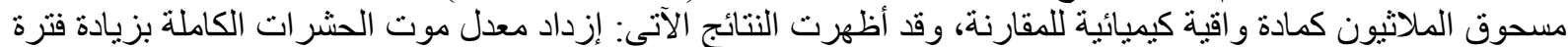

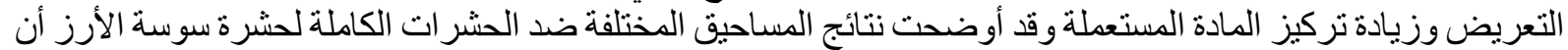

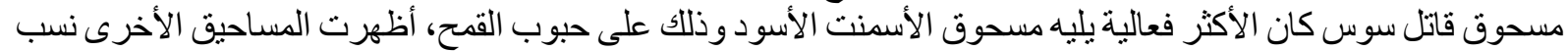

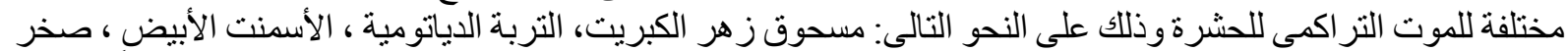

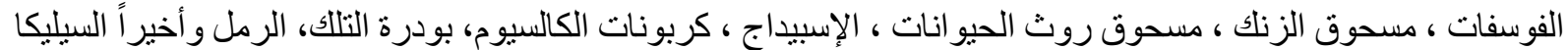

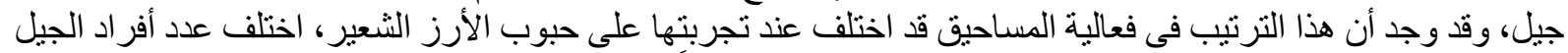

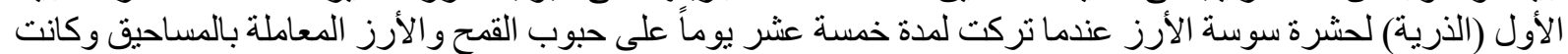

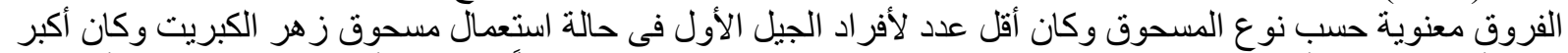

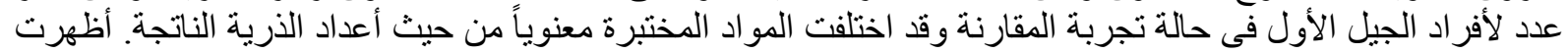

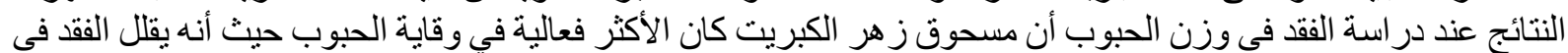

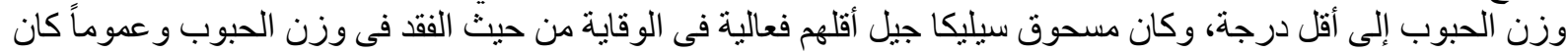

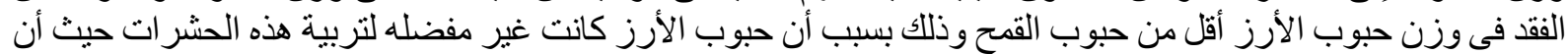

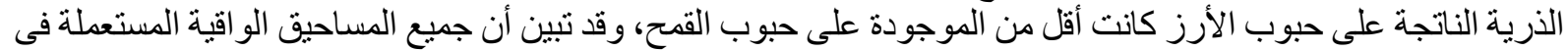
هذه الدر اسة قد أدت إلى زيادة نسبة الإنبات لحبوب الأن الأرز و القمح. 